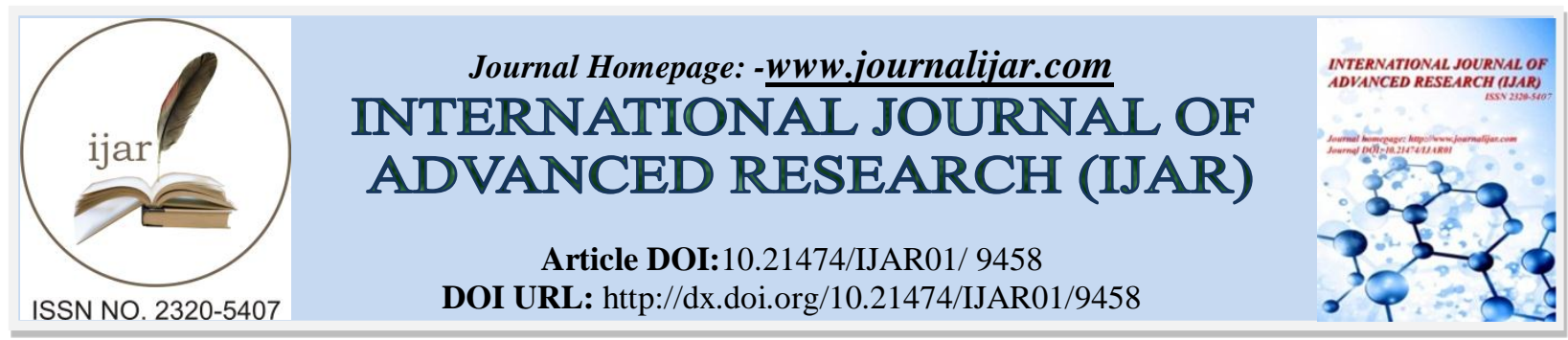

RESEARCH ARTICLE

\title{
TO STUDY THE DISTRIBUTION OF ABO BLOOD GROUP AND RH (D) FACTOR AMONG ETHNIC POPULATION OF LADAKH REGION IN THE AGE GROUP OF 15- 45: A CROSSECTIONAL STUDY.
}

Dr. Kaniz Fatima ${ }^{1}$ and Dr. Yangchen Dolma ${ }^{2}$.

1. Senior Resident,Department Of Physiology,Government Medical college Jammu.

2. Assistant Professor,Department of Community Medicine Government Medical College Kathua.

\section{Manuscript Info}

Manuscript History

Received: 26 May 2019

Final Accepted: 28 June 2019

Published: July 2019

Key words:-

Blood group, Antisera,

Agglutination,Antigen..

\section{Abstract}

The study was done to assess the distribution of blood group among Ethnic population of Ladakh region in the age group of 15-45. A crossectional study was conducted for a period of two year in the month of June and July 2018.Random Sampling was done from all the zones of Tehsil Leh.Line listing of all eligible candidates in the age group of $15-25$ years was done. Standard methods was adopted for Blood grouping.It was done by Antigen Antibody agglutination test by commercially available standard antiseras Anti A,Anti B,Anti AB and Anti D done by test tube method. Data was entered in Microsoft excel and analysis done by SPSS and expressed in terms of number and percentage. Majority of the subjects were in the age group of 25-35.Most of the subjects belong to blood group A (53.8\%) followed by $23 \%$ of blood group B and least blood group constitute $\mathrm{O}$ blood group (3.8\%).Blood group A +ve was common among females, blood group $B$ among males and almost equal distribution of blood group AB. Most of the participants were in the age group of 35-45 years.Regarding the Rh D status , 119 were $\mathrm{Rh}+\mathrm{ve}$ and 11 were $\mathrm{Rh}-$ ve. $\mathrm{A}+\mathrm{ve}$ was most common followed by $\mathrm{B}+$ ve and $\mathrm{AB}+\mathrm{ve}$.

Copy Right, IJAR, 2019,. All rights reserved.

\section{Introduction:-}

Blood is classified into Blood group according to certain substances are present or not.These include antigens found on the surface of your red blood cells and the antibodies which are mainly found in plasma.The most common system used for classifying blood are ABO Blood group system and the Rhesus type system.ABO blood group System for bllod typing is based on which of the antigen you have on red blood cells.If antigen is present on red blood cell, it is called $\mathrm{Rh}+\mathrm{ve}$. If not,it is said to be $\mathrm{RH}$ - ve.

\section{Objective:}

The present study was done to assess the distribution of blood group among Ehnic population of Ladakh region in the age group of 15-45.the study was first of its kind in this part of the world. 


\section{Methodology:-}

A crossectional study was conducted for a period of two year in the month of June and July 2018.Random Sampling was done from all the zones of Tehsil Leh .Line listing of all eligible candidates in the age group of $15-25$ years was done. $25 \%$ of the subjects were selected by Lottery method to get equal representation of the area.The total sample thus comes out to be 130.Informed consent was taken after explaining the purpose of study and for collecting blood samples to all the participants. Standard methods was adopted for Blood grouping. It was done by Antigen Antibody agglutination test by commercially available standard anti seras Anti A, Anti B, Anti AB and Anti D done by test tube method. ${ }^{1}$ Four different tubes were labelled. To every tube with antisera one drop of 5\% cell suspension was added and each sample was macroscopically observed for agglutination. Positive Agglutination indicates positive reaction to respective group or Rh factors. Negative Agglutination indicates negative reaction to respective group or rhesus factor. ${ }^{2}$

Data was entered in Microsoft excel and analysis done by SPSS and expressed in terms of number and percentage.

\section{Results and Discussion:-}

130 subjects were selected randomly. Out of 130, 63 were and 67 females . Majority were in the age group of 2535.Table 1 depicts the distribution of different blood group. Majority of the subjects belong to blood group A $(53.8 \%)$ followed by $23 \%$ of blood group B and least blood group constitute O blood group (3.8\%).

Table 2 shows gender wise distribution of blood group.Blood group A +ve being common among females, blood group $\mathrm{B}$ among males and almost equal distribution of blood group $\mathrm{AB}$.

Table 1:-Frequency distribution of different blood group among Ethnic population

\begin{tabular}{|c|c|c|c|c|l|}
\hline Blood group & $\mathrm{A}$ & $\mathrm{B}$ & $\mathrm{AB}$ & $\mathrm{O}$ & Total \\
\hline Number & 70 & 30 & 25 & 5 & 130 \\
\hline Percentage & $53.8 \%$ & $23 \%$ & $19.2 \%$ & $3.8 \%$ & $100 \%$ \\
\hline
\end{tabular}

Table 2:-Frequency distribution of different blood group according to Gender

\begin{tabular}{|l|l|l|l|l|}
\hline Gender & A & B & AB & O \\
\hline Males & 30 & 17 & 13 & 3 \\
\hline Females & 40 & 13 & 12 & 2 \\
\hline Total & 70 & 30 & 25 & 5 \\
\hline
\end{tabular}

Mohd S.Jaff et al conducted a study in Kurds. The most prevalent blood group was o (37.16\%) followed by Blood group A (32.47\%)and $\mathrm{B}(23.84 \%)$ while the least prevalent group was $\mathrm{AB}$.The majority (91.73\%) were $\mathrm{Rh}+\mathrm{ve}$ and $8.27 \%$ were $\mathrm{Rh}-\mathrm{ve} .^{3}$

Hussain Iftikhar et al in their study found that in both Danyore and Gilgit cities, the highest blood group found was $\mathrm{A}+\mathrm{ve}$ followed by A-ve , $\mathrm{B}+\mathrm{ve}, \mathrm{AB}+\mathrm{ve}$ and so on. The $\mathrm{B}-\mathrm{ve}$ blood group is the least blood group. ${ }^{4}$

Chaurasia Kumar et al did a study in Madhya Pradesh at a tertiary care hospital.The most common blood group was B+ve ( $35.9 \%$ ) followed by $\mathrm{O}$

( $30.9 \%$ ). Out of these, $95 \%$ donors were $\mathrm{Rh}+\mathrm{ve}$ while $4.5 \%$ were $\mathrm{Rh}-\mathrm{ve}$.Age wise distribution shows most of the participants in the age group of $35-45$ years. ${ }^{5}$

Regarding the $\mathrm{Rh} \mathrm{D}$ status, 119 were $\mathrm{Rh}+\mathrm{ve}$ and 11 were $\mathrm{Rh}-\mathrm{ve}$. $\mathrm{A}+\mathrm{ve}$ was most common followed by $\mathrm{B}+$ ve and $\mathrm{AB}+\mathrm{ve}$.

Ola Jahen Pour et al, the most common blood group was o(52.3\%) and least common was AB (31.8\%).97.7\% of the blood donors were $\mathrm{Rh}+\mathrm{ve}$ and rest were $\mathrm{Rh}$-ve.Most donors were young adults representing the age group of 19- $29 .{ }^{6}$

Table 3:-Frequency distribution Of different blood group according to Age.

\begin{tabular}{|l|l|l|l|l|}
\hline Age group & A & B & AB & O \\
\hline $15-25$ & 15 & 8 & 7 & 0 \\
\hline
\end{tabular}




\begin{tabular}{|l|l|l|l|l|}
\hline $25-35$ & 30 & 12 & 12 & 3 \\
\hline $35-45$ & 25 & 10 & 11 & 2 \\
\hline Total & 70 & 30 & 25 & 5 \\
\hline
\end{tabular}

Table 3: Frequency distribution Of different blood group according to $\mathrm{Rh}$ Status

\begin{tabular}{|l|l|c|}
\hline ABO Blood group & Rh+ve & Rh -ve \\
\hline$A(n=70)$ & $65(92.8 \%)$ & $5(7.14 \%)$ \\
\hline$B(n=30)$ & $29(96.6 \%)$ & $1(3.33 \%)$ \\
\hline$A B(n=25)$ & $24(96 \%)$ & $1(4 \%)$ \\
\hline$O(n=5)$ & $4(80 \%)$ & $1(20 \%)$ \\
\hline
\end{tabular}

\section{Conclusion:-}

Majority of the subjects were in the age group of 25-35.Most of the subjects belong to blood group A (53.8\%) followed by $23 \%$ of blood group B and least blood group constitute O blood group (3.8\%).Blood group A +ve was common among females, blood group B among males and almost equal distribution of blood group AB. Most of the participants were in the age group of 35-45 years.Regarding the Rh D status, 119 were Rh+ve and 11 were $\mathrm{Rh}-$ ve. $\mathrm{A}+\mathrm{ve}$ was most common followed by $\mathrm{B}+\mathrm{ve}$ and $\mathrm{AB}+\mathrm{ve}$.

Authors Contribution:

Dr Kaniz Fatima collected the data.Dr Yangchen Dolma prepared the manuscript.

\section{Acknowledgement:-}

The authors thank all the participants for their cooperation.

\section{References: -}

1. Singh Pawan et al,Distribution of ABO Blood group and Rh (D) factor among blood donors in Haryana: International Journal of Biomedical and advance research $2015,6(03): 249-252$.

2. Johanpour et al, $\mathrm{ABO}$ and $\mathrm{Rh}$ Blood group distribution and frequency among blood donors at Kilimanjaro Christian Medical center,Moshi,Tanzania.Biomed central (2017) 10:738:1186/13104-017- 3037- 3

3. Jaff Mohammad et al,Journal of Blood Medicine 2010 : 143-146

4. Hussain Iftikhar et al:Blood group distribution pattern among limited adult hman population of district Gilgit,Gilgit Baltistan, Pakistan: International Journal of Pure and Applied Zoology,vol 6,Issue 2,PP:1824,2018 .

5. K Chaurasia et al, A Study of distribution of ABO and RH blood group system among blood donors at a tertiary care hospital. Journal of Evolution of Medical and Dental Science, 2278-4748 / vol 4/Issue 18/ March 02,2015 .

6. Zahra Ghobodian Et al, Distribution of ABO Rh blood grouping in a major Ethnic group of west Iran, the Kurdish population. Asian Journal of Medical Sciences/ July - Sept 2014 / Vol 5 / Issue 3. 